\title{
Article
}

\section{High Temperature Creep Behaviour of Cast Nickel-Based Superalloys INC 713 LC, B1914 and MAR-M247}

\author{
Marie Kvapilova *, Petr Kral D, Jiri Dvorak and Vaclav Sklenicka \\ Institute of Physics of Materials CAS, Žižkova 22, 61662 Brno, Czech Republic; pkral@ipm.cz (P.K.); \\ dvorak@ipm.cz (J.D.); vsklen@ipm.cz (V.S.) \\ * Correspondence: kvapilova@ipm.cz; Tel.: +420-532-290-374
}

\begin{abstract}
Cast nickel-based superalloys INC713 LC, B1914 and MAR-M247 are widely used for high temperature components in the aerospace, automotive and power industries due to their good castability, high level of strength properties at high temperature and hot corrosion resistance. The present study is focused on the mutual comparison of the creep properties of the above-mentioned superalloys, their creep and fracture behaviour and the identification of creep deformation mechanism(s). Standard constant load uniaxial creep tests were carried out up to the rupture at applied stress ranging from 150 to $700 \mathrm{MPa}$ and temperatures of $800-1000^{\circ} \mathrm{C}$. The experimentally determined values of the stress exponent of the minimum creep rate, $n$, were rationalized by considering the existence of the threshold stress, $\sigma_{0}$. The corrected values of the stress exponent correspond to the power-law creep regime and suggest dislocation climb and glide as dominating creep deformation mechanisms. Fractographic observations clearly indicate that the creep fracture is a brittle mostly mixed transgranular and intergranular mode, resulting in relatively low values of fracture strain. Determined main creep parameters show that the superalloy MAR-M247 exhibits the best creep properties, followed by B1914 and then the superalloy INC713 LC. However, that each of the investigated superalloys can be successfully used for high temperature components fulfils the required service loading conditions.
\end{abstract}

Keywords: creep; nickel-based superalloy; fracture

Citation: Kvapilova, M.; Kral, P.; Dvorak, J.; Sklenicka, V. High Temperature Creep Behaviour of Cast Nickel-Based Superalloys INC 713 LC, B1914 and MAR-M247. Metals 2021, 11, 152. https://doi.org/ $10.3390 /$ met11010152

Received: 30 November 2020 Accepted: 9 January 2021 Published: 14 January 2021

Publisher's Note: MDPI stays neutral with regard to jurisdictional clai$\mathrm{ms}$ in published maps and institutional affiliations.

Copyright: $\odot 2021$ by the authors. Licensee MDPI, Basel, Switzerland. This article is an open access article distributed under the terms and conditions of the Creative Commons Attribution (CC BY) license (https:// creativecommons.org/licenses/by/ $4.0 /)$.

\section{Introduction}

Cast nickel-based superalloys have been widely utilized for high temperature components, such as disc rotors, turbine blades and integral wheels. Ni-based superalloys exhibit a variety of excellent characteristics, including good castability, good strength levels, superior creep properties and hot corrosion resistance at high temperatures. Every rotation parts of the component work at a higher temperature and are subjected for a prolonged time to centrifugal forces, and thus to the resulting tensile stress. This means that the creep will probably be the major mode of damage and will determine the component's lifetime. Nickel, as a solvent with FCC (face centered cubic structure) crystal structure, is known for its low rates of thermally activated processes. The mechanical properties of Ni-based superalloys strongly depend on their microstructures, which are controlled by their chemical compositions and processing conditions. Different alloying elements can significantly affect the creep properties and lifetime of components at high operating temperatures. Research the high temperature creep properties of variously alloying nickel-based superalloys for producing costly, highly reliable parts with regard to their further applications and cost seems to be strongly needed. Therefore, this study is focused on the comparison of high temperature creep behaviour of three nickel-based superalloys, namely Inconel 713 LC, B1914 and MAR-M247, and on determining the factors influencing the differences in their creep resistance and lifetime $[1,2]$.

Microstructures of all the as-cast superalloys have a typical dendritic character. Segregation processes during solidification led to the formation of significant chemical het- 
erogeneities in the microstructure. When solidified, usually coarsened gamma prime precipitates were formed inside the eutectic zones. The superalloys contain approximately $60 \%$ semi-coherent $\gamma^{\prime}$ phase $\mathrm{Ni}_{3}(\mathrm{Al}, \mathrm{Ti})$ of cuboidal shape in $\gamma$ matrix. Alloying by $\mathrm{Mo}$, $\mathrm{Ti}$, $\mathrm{Cr}, \mathrm{Zr}$ and other additives leads to further solid solution and precipitation strengthening by carbides (and borides in the case of B1914) of these elements of the matrix, and thus to an increase in the strengthening effect of the gamma phase [3].

Superalloy Inconel 713 and its low carbon version LC, which represent the first generation of the nickel-based alloys, have been used for more than 50 years, but they are still desired for producing components of combustion engines such as integral wheels or turbine blades due to good withstanding of a high-thermo-mechanics load. They have a cuboid morphology of gamma prime $\gamma^{\prime}$ phase divided by a channel of solid solution $\gamma$ (Ni-Cr). Reduced carbon content leads to lower ability of the formation of carbides. For such a type of alloy, therefore, a higher carbon content is not desirable, and for improving the properties of the grain boundaries, boron and the coherent intermediate phase $\gamma^{\prime}$ precipitates are used as the main strengthening elements [4-8].

Superalloy MAR-M247 is included in the second generation of nickel-based superalloys, developed in 1970 and widely employed in the aerospace industry for producing advanced turbine blades and rotating parts [3]. The structure of MAR-M247 is similar to INC713 LC and contains circa $60 \%$ of $\gamma^{\prime}$ phase $\mathrm{Ni}_{3} \mathrm{Al}$ in matrix $\gamma$ strengthened by cobalt, molybdenum, tungsten, hafnium, chromium and a higher volume of tantalum $[9,10]$. These elements, primarily in the form of carbides and borides, precipitate mainly at the grain boundaries and contribute to creep performance by pinning the grain boundaries and, subsequently, preventing the grain boundaries from grain boundary sliding and migration [11]. The addition of element Ta (characterized by its high melting point) can especially curb the coagulation and growth of the $\gamma^{\prime}$ phase [12].

The third superalloy studied in this article is B1914 alloy, which began to be used approximately forty years ago. It belongs to the group of nickel-based superalloys with a higher volume of boron, so-called BC superalloys. The microstructure of B1914 superalloy is based on similar features as INC 713LC and MAR-M247-dendritic $\gamma$ matrix and cuboidal $\gamma^{\prime}$ phase. However, BC alloys were developed to reduce the carbon content and increase boron content to promote boride formation [13-16].

In all three superalloys, the carbides of the type $\mathrm{M}_{23} \mathrm{C}_{6}, \mathrm{MC}$ are present; however, carbides $\mathrm{M}_{6} \mathrm{C}$ are only found in MAR-M247 and B1914 [17]. Nevertheless, it has been observed that these carbides are not stable. The carbides may undergo changes to their size and morphology due to operating temperature and applied stress. Carbides of MC type, during long term high-temperature exposition, can decompose to $\mathrm{M}_{6} \mathrm{C}$ or $\mathrm{M}_{23} \mathrm{C}_{6}$ and release refractory elements, such as titanium, tungsten, niobium, molybdenum and chromium, that quickly form deleterious TCP (topologically close-packed) phases. This situation was observed in the temperature interval $760-980^{\circ} \mathrm{C}$ [17]. These changes could also influence the creep properties of the alloys during long-term high-temperature exposure.

The superalloy B1914 is more doped by boron, which extends the solidificationfreezing range, and borides with tetragonal structure are formed mainly in the final stages of solidification. Most borides are located either in grain boundaries in the immediate vicinity of carbides or solidification pores. The $\mathrm{M}_{3} \mathrm{~B}_{2}$ boride is stable below $1166^{\circ} \mathrm{C}$ and does not decompose at lower temperatures [18-21].

It was observed that adding boron to the nickel-rich grain boundary will induce disordering in the vicinity of the grain boundary [22]. When the dislocations pile-up at the grain boundaries, it is difficult for them to move across the grain boundaries. However, in the case of grain boundary disordering by boron, the dislocation transfer across the boundary is easier and it can cause dissipation of strain at the head of the dislocation pileups. So, boron is thought to make dislocations cross slip and transfer across grain boundaries easier and, consequently, reduce the tendency for crack nucleation, thereby lessening the risk of the creation of premature micro-cracks [13-16,23]. 
The aim of this article is to compare the high-temperature creep behaviour of three nickel-based superalloys (including creep parameters such as the minimum creep rate, creep life, creep fracture deformation) in relation to their chemical composition, influencing creep controlled deformation and fracture mechanisms.

The selection of structural materials of high temperature components is governed by the need to meet demands for a component's higher efficiency, safe operation and lower cost and weight. The selection of superalloys has, to a large extent, been based on metallurgical experience, but the modern trend is that a more fundamental understanding is needed to fully utilize the potential of these high temperature materials. Thus, the results of this study could be valuable for the cost-effective selection of materials and the design of relevant high temperature components in engineering applications.

\section{Materials and Methods}

All three nickel-based superalloys, INC 713 LC, MAR-M247 and B1914, were produced by foundry PBS Velká Bíteš, Velká Bíteš, Czech Republic. Pre-cast rods have a diameter of $15 \mathrm{~mm}$ and were fabricated by investment casting [24]. Pouring temperature into the mould for INC $713 \mathrm{LC}$ was $1360 \pm 15{ }^{\circ} \mathrm{C}$ and the superalloy was investigated in the as-received state, as it is often used in practice. The pouring temperature of the melt into the mould for MAR-M247 was $1300 \pm 15^{\circ} \mathrm{C}$. After casting, the superalloy was processed by hot isostatic pressing (HIP) procedure $\left(1200^{\circ} \mathrm{C} / 4 \mathrm{~h}, 100 \mathrm{MPa}\right)$ (BODYCOTE Hot Isostatic Pressing n.v., Sint-Niklaas, Belgium). Two-step heat treatment followed, consisting of solution annealing at $1200^{\circ} \mathrm{C}$ for $2 \mathrm{~h}$ and precipitation annealing at $870{ }^{\circ} \mathrm{C}$ for $24 \mathrm{~h}$. The pre-cast rods (pouring temperature $1360 \pm 15^{\circ} \mathrm{C}$ ) of superalloy B1914 were subjected to HIP treatment at the temperature $1155^{\circ} \mathrm{C}$ and the pressure $100 \mathrm{MPa}$ for $3 \mathrm{~h}$ in argon atmosphere, followed by two-step heat treatment consisting of solution annealing at the temperature $1080{ }^{\circ} \mathrm{C}$ for $4 \mathrm{~h}$ with cooling in air and precipitation annealing at the temperature $900{ }^{\circ} \mathrm{C}$ for $10 \mathrm{~h}$ with cooling in air.

The chemical compositions of all three superalloys are in Table 1. The main differences in content of various elements are highlighted in bold.

Table 1. Chemical compositions of nickel-base superalloys (in wt.\%).

\begin{tabular}{cccccccccccccc}
\hline Superalloys & $\mathbf{C}$ & $\mathbf{C r}$ & $\mathbf{C o}$ & $\mathbf{M o}$ & $\mathbf{W}$ & $\mathbf{T a}$ & $\mathbf{T i}$ & $\mathbf{A l}$ & $\mathbf{B}$ & $\mathbf{Z r}$ & $\mathbf{H f}$ & $\mathbf{N b}$ & $\mathbf{N i}$ \\
\hline INC 713 LC & 0.04 & 11.85 & - & $\mathbf{4 . 4 5}$ & - & 0.05 & 0.72 & 5.80 & 0.015 & 0.11 & - & $\mathbf{2 . 2 7}$ & bal. \\
MAR-M247 & 0.15 & 8.37 & $\mathbf{9 . 9 2}$ & 0.67 & $\mathbf{9 . 9 2}$ & $\mathbf{3 . 0 5}$ & 1.01 & 5.42 & 0.015 & 0.04 & $\mathbf{1 . 3 7}$ & 0.03 & bal. \\
B1914 & 0.009 & 9.99 & $\mathbf{9 . 6 3}$ & 2.9 & - & - & $\mathbf{5 . 2 8}$ & 5.51 & $\mathbf{0 . 0 8}$ & 0.002 & - & - & bal. \\
\hline
\end{tabular}

The superalloy INC 713 LC exhibits a higher amount of molybdenum and niobium in comparison with the remaining investigated superalloys. The MAR-M247 is more alloyed by cobalt, tungsten, tantalum and hafnium, and B1914 has a higher content of titanium and boron. The melting points of the three superalloys are in Table 2.

Table 2. Melting temperatures for superalloys under investigation.

\begin{tabular}{cccc}
\hline Superalloys & INC 713 LC & MAR-M247 & B1914 \\
\hline Melting temperature $\left({ }^{\circ} \mathbf{C}\right)$ & $1268-1288$ & 1390 & 1335 \\
\hline
\end{tabular}

The microstructures of the superalloys in the as-received state before the creep test are shown in Figure 1a-c. The as-received microstructures of all three superalloys consist of coarse dendritic grain, with a grain size of about $1.0 \mathrm{~mm}$ for INC $713 \mathrm{LC}, 4.0 \mathrm{~mm}$ for MAR-M247 and $2.3 \mathrm{~mm}$ for B1914, respectively. The grain size was measured by the linear intercept method. The material structures contain $\gamma$ matrix with dispersed gamma prime $\gamma^{\prime}$ strengthening cubic precipitates (about 60 vol. \%) and discrete carbides $\mathrm{M}_{23} \mathrm{C}_{6}$ (usually $\mathrm{Cr}_{23} \mathrm{C}_{6}$ ), elongated $\mathrm{MC}$ carbides along the grain boundaries and the $\mathrm{M}_{6} \mathrm{C}$ type of carbide, which were determined in [2,25]. In B1914, the boron atoms are either solutionized in the 
matrix or present at the grain boundaries. Coarse primary $\gamma^{\prime}$ phase particles were observed in all superalloys with an average size of $\sim 0.5-1.5 \mu \mathrm{m}$.

Standard uniaxial constant load creep tests in tension were carried out at the temperatures $800,900,950$ and $1000{ }^{\circ} \mathrm{C}$ (testing temperature was maintained within $\pm 0.5 \mathrm{~K}$ of the desired value) at an applied stress ranging from 150 to $700 \mathrm{MPa}$. The creep machines (home-made construction) were equipped with a linear variable differential transducer for the continuous measuring of creep elongations and the data were recorded digitally and computer processed (creep elongation was measured with a sensitivity of $5 \times 10^{-6}$ ). All creep tests were run up to the final creep fracture of the specimens. The fracture elongations were checked by a Gauss comparator. The cylindrical creep specimens with a gauge length of $50 \mathrm{~mm}$ and a diameter of $3.5 \mathrm{~mm}$ were used in this study.

Micrographs of the structure of the as-received states and analyses of the fracture surfaces were obtained using scanning electron microscopy (SEM, Tescan LYRA 3 XMH, Brno, Czech Republic). The specimens were prepared for microscopy by metalographic polishing and etching (etching solution $10 \mathrm{~mL} \mathrm{HNO}_{3}+5 \mathrm{~mL} \mathrm{HCl}$ ). The fracture surfaces and the longitudinal cross-section of the specimens were observed by SEM-Tescan, Lyra.
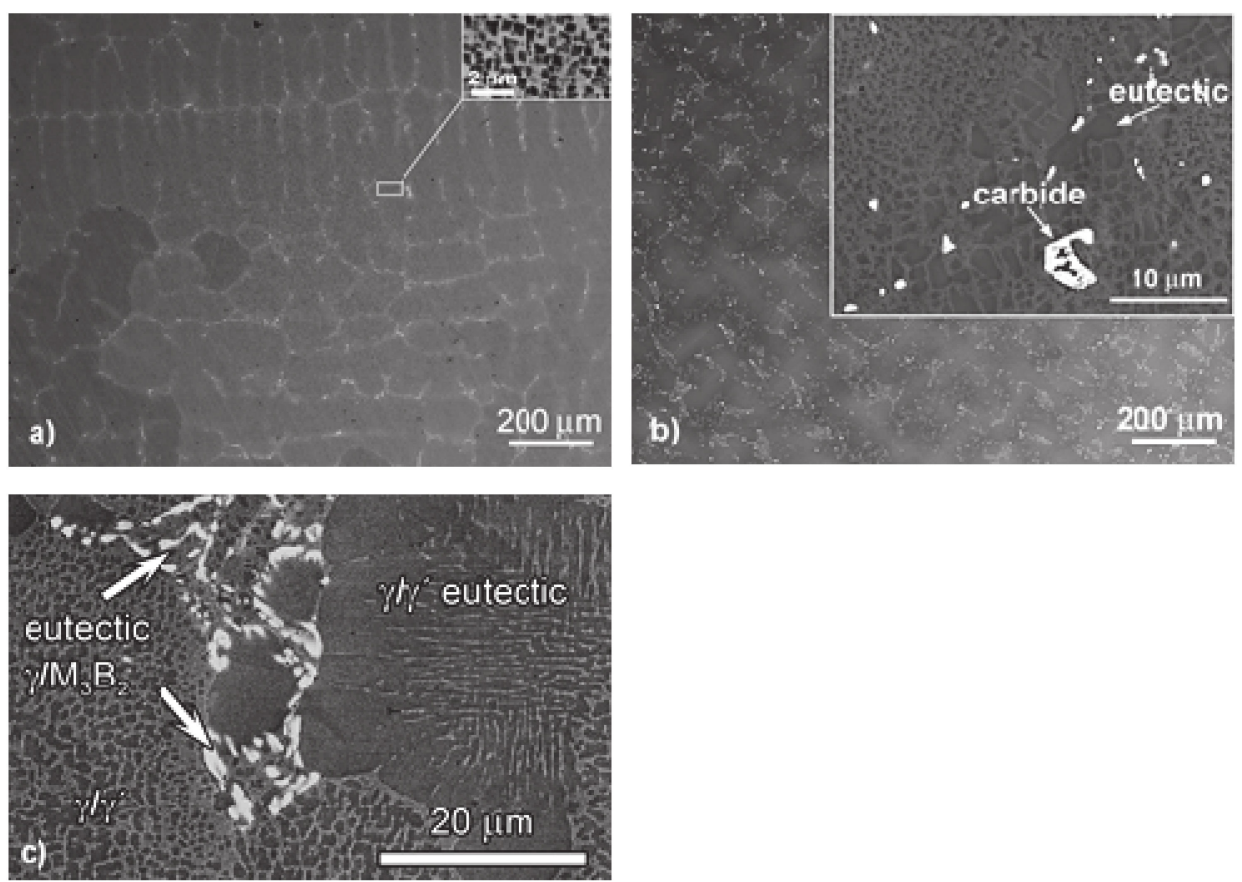

Figure 1. The microstructure of the as-received states of superalloys: (a) INC 713 LC, (b) MAR-M247, (c) B1914 [10].

\section{Results}

\subsection{Creep Behaviour}

The comparisons of the creep behaviour of three studied superalloys using the time dependences of strain and strain rate under the same loading conditions are illustrated by Figures 2-5. The time dependences of creep strain are shown on (a) parts of Figures 2-5. These curves on (a) type of Figures 2-5 can be replotted as the time dependence of creep rate (b) part of Figures 2-5, where the individual stages of creep can be more easily identified. The very important creep characteristic for the recognition of operating creep deformation mechanism(s) - the minimum creep rate—can be easily determined from these creep curves. From Figures $2 b-5 b$, it is clear that after a very short primary stage of creep, the secondary stage of creep is represented only by an inflection point on the curve of the time dependence of the strain rate, where the creep rate reached its minimum value. This way, we can easily determine the value of the minimum creep rate. Then, the tertiary creep phase begins. 


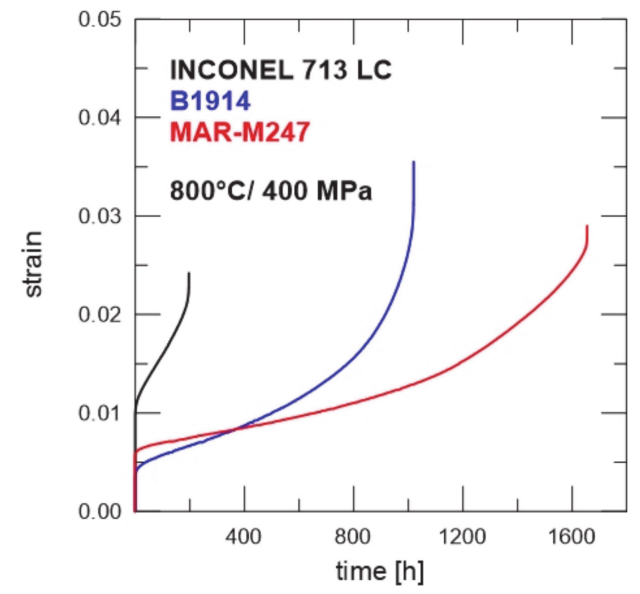

(a)

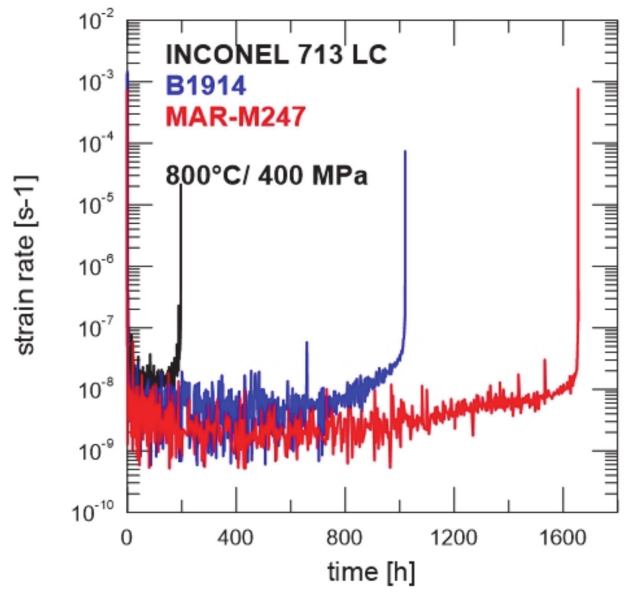

(b)

Figure 2. The comparison of time dependences of (a) strain and (b) creep rate for superalloys INC $713 \mathrm{LC}, \mathrm{B} 1914$ and MAR-M247 crept at $800{ }^{\circ} \mathrm{C}$ and $400 \mathrm{MPa}$.

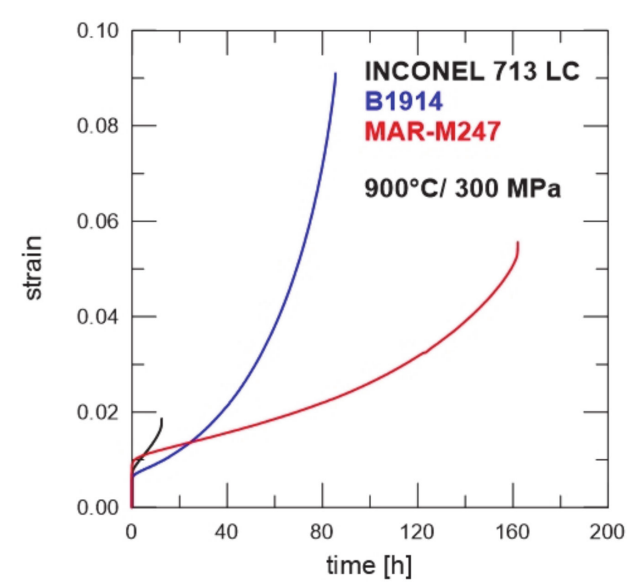

(a)

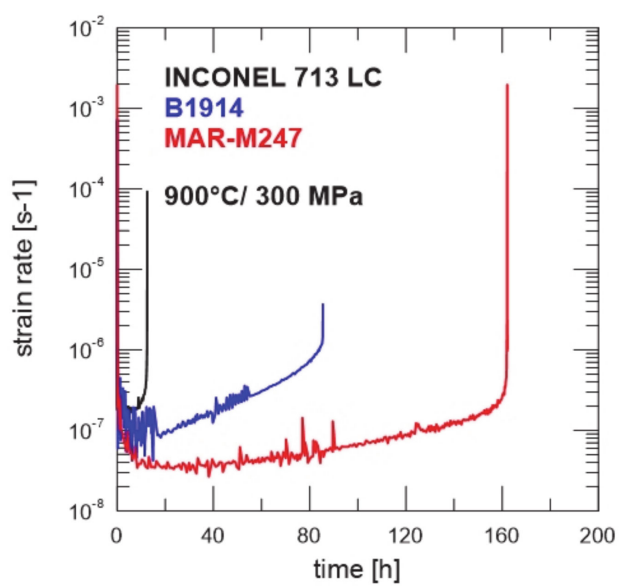

(b)

Figure 3. The comparison of time dependences of (a) strain and (b) creep rate for superalloys INC 713 LC, B1914 and MAR-M247 crept at $900{ }^{\circ} \mathrm{C}$ and $300 \mathrm{MPa}$.

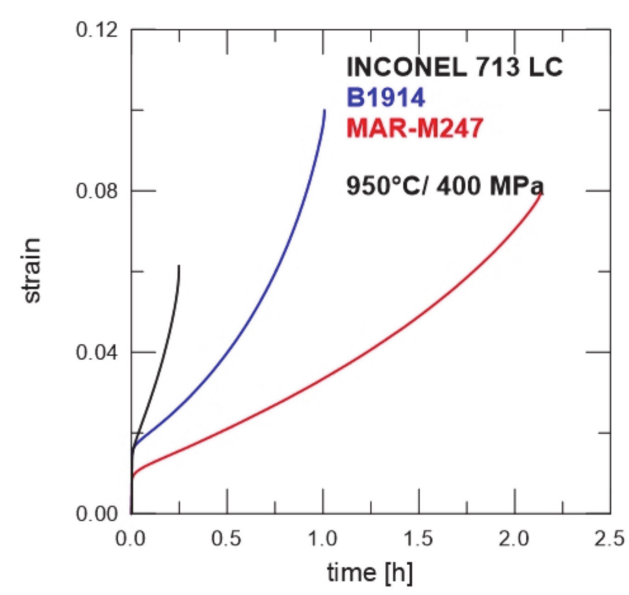

(a)

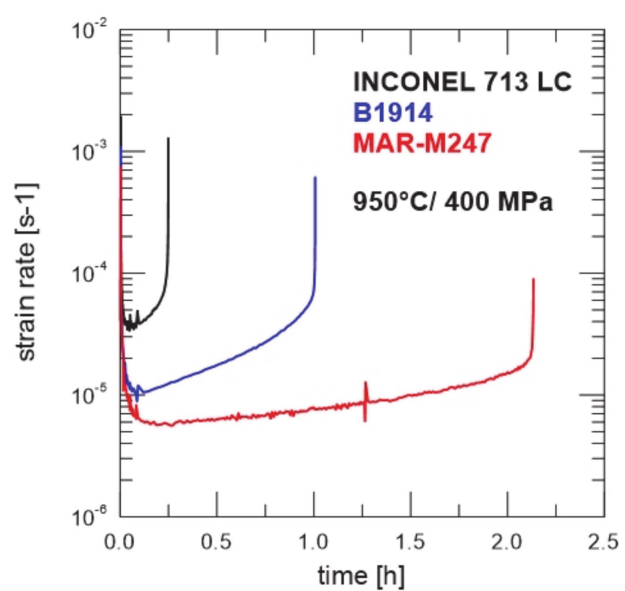

(b)

Figure 4. The comparison of time dependences of (a) strain and (b) creep rate for superalloys INC 713 LC, B1914 and MAR-M247 crept at $950{ }^{\circ} \mathrm{C}$ and $400 \mathrm{MPa}$. 


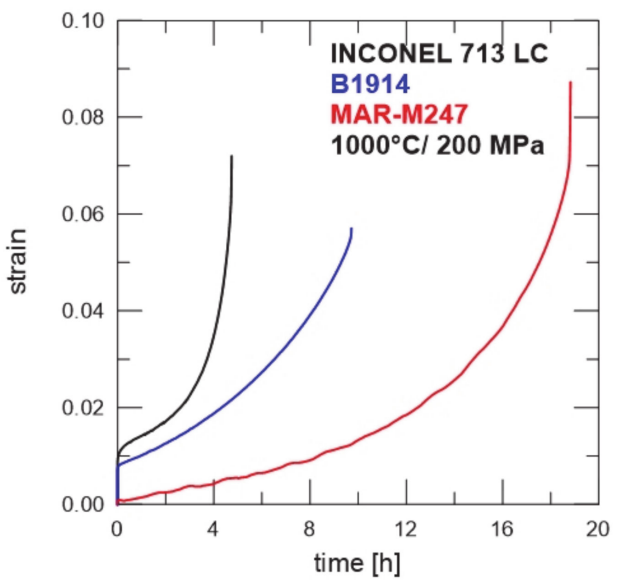

(a)

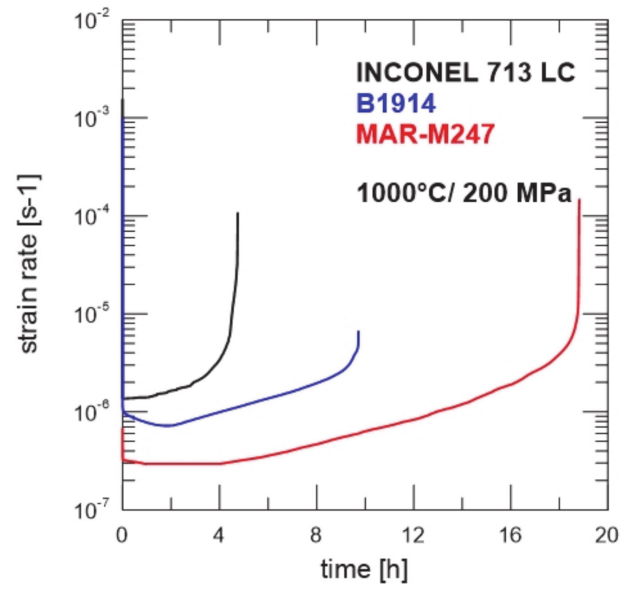

(b)

Figure 5. The comparison of time dependences of (a) strain and (b) creep rate for superalloys INC $713 \mathrm{LC}, \mathrm{B} 1914$ and MAR-M247 crept at $1000^{\circ} \mathrm{C}$ and $200 \mathrm{MPa}$.

The mutual comparison of the main creep characteristics-the minimum creep rate, the time to fracture and the fracture elongation-for all three superalloys at the same loading conditions can be made using the stress dependences of these characteristics as shown in Figures $6 a, b-8 a, b$. For better clarity, Figures $6 a$ and $7 \mathrm{a}$ and Figures $6 \mathrm{~b}$ and $7 \mathrm{~b}$ describe creep characteristics at two temperatures ranges, $800{ }^{\circ} \mathrm{C}$ and $900{ }^{\circ} \mathrm{C}$, and $950{ }^{\circ} \mathrm{C}$ and $1000{ }^{\circ} \mathrm{C}$, respectively.

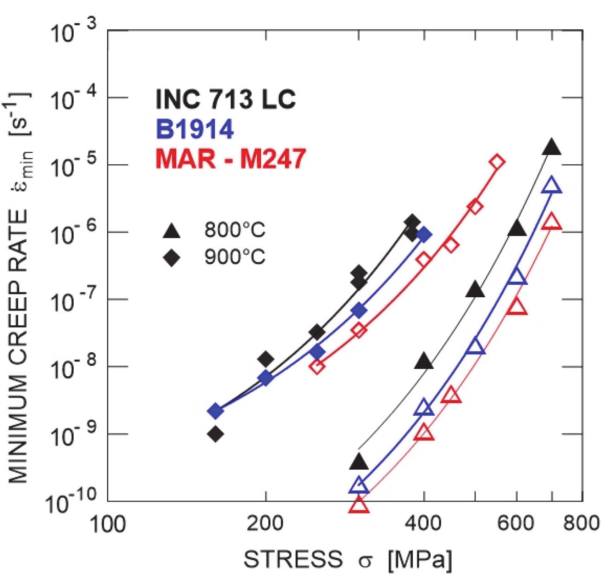

(a)

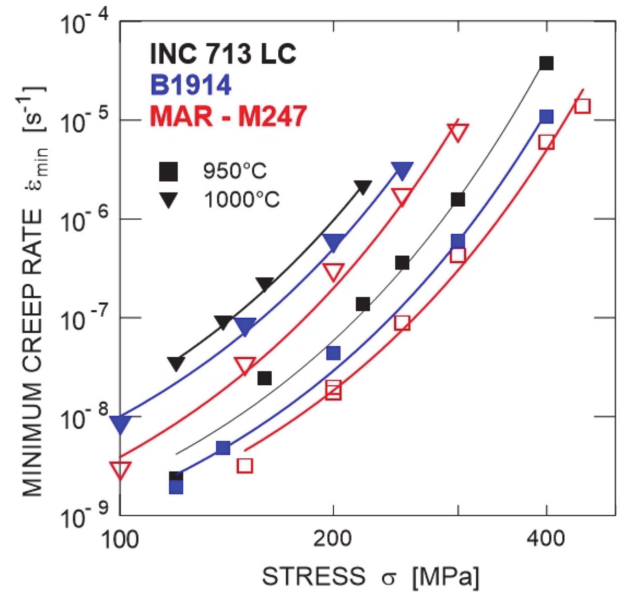

(b)

Figure 6. The comparison of stress dependences of minimum creep rate for superalloys INC $713 \mathrm{LC}$, B1914 and MAR-M247 crept at (a) $800{ }^{\circ} \mathrm{C}$ and $900{ }^{\circ} \mathrm{C}$, (b) $950{ }^{\circ} \mathrm{C}$ and $1000^{\circ} \mathrm{C}$ at different applied stresses. 


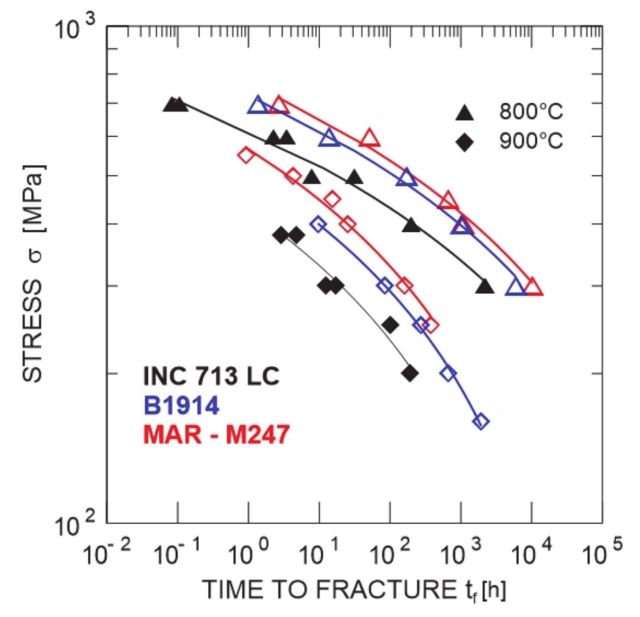

(a)

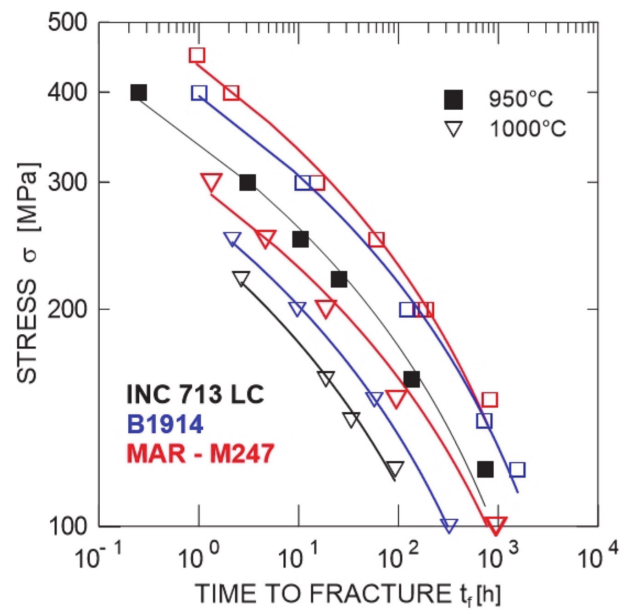

(b)

Figure 7. The comparison of stress dependences of time to fracture for superalloys INC 713 LC, B1914 and MAR-M247 crept at (a) $800{ }^{\circ} \mathrm{C}$ and $900{ }^{\circ} \mathrm{C}$, (b) $950{ }^{\circ} \mathrm{C}$ and $1000^{\circ} \mathrm{C}$ at different applied stresses.

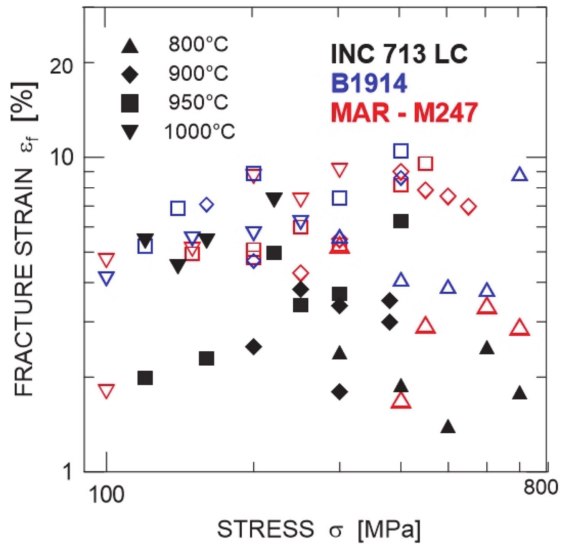

(a)

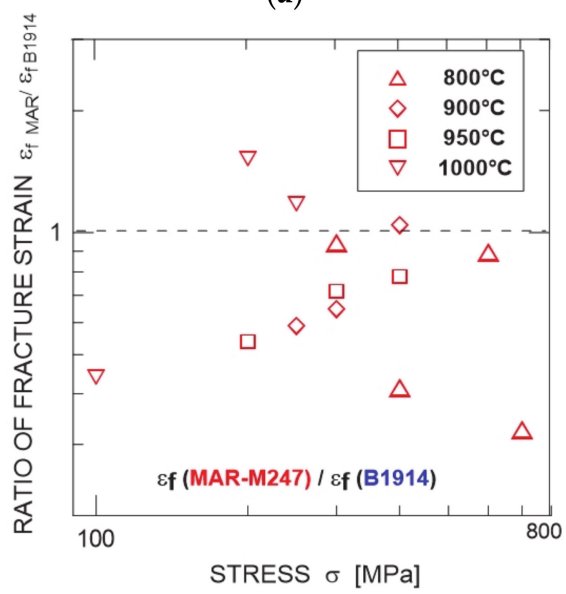

(c)

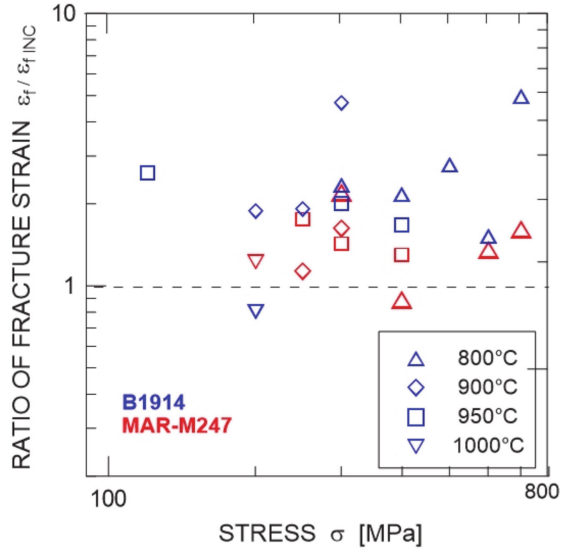

(b)

Figure 8. (a) The comparison of stress dependences of fracture strains for superalloys INC 713 LC, B1914 and MAR-M247 at applied creep temperatures of $800^{\circ} \mathrm{C}, 900{ }^{\circ} \mathrm{C}, 950{ }^{\circ} \mathrm{C}$ and $1000{ }^{\circ} \mathrm{C}$, respectively. (b) Stress dependence of the ratio of fracture strain of B1914 and MAR-M247 to the fracture strain of INC $713 \mathrm{LC}$, and (c) stress dependence of the ratio of fracture strains of MAR-M247/B1914 at applied creep temperatures of $800^{\circ} \mathrm{C}, 900^{\circ} \mathrm{C}, 950^{\circ} \mathrm{C}$ and $1000^{\circ} \mathrm{C}$, respectively. 
Inspection of Figures 6 and 7 leads to several findings. Firstly, the stress dependences of the minimum creep rate show the lowest values for the superalloy MAR-M247, the superalloy B1914 exhibits a slightly higher level of minimum creep rate $\dot{\varepsilon}_{\min }$, and the superalloy INC-713 LC has the highest values of $\dot{\varepsilon}_{\text {min }}$, which indicate the fastest operating creep processes. Secondly, the values of the creep life (Figure 7) exhibit decreasing creep resistance from the longest time to fracture (MAR-M247) to the shortest (INC-713 LC).

Examination of Figure 6 revealed that the stress dependences of $\dot{\varepsilon}_{\min }$ for every temperature have the same trend. However, the slopes, and therefore the values of the apparent stress exponents of the creep rate $n$ (Equation (1)), are slightly different for individual temperatures, and at a constant temperature are changing with the applied stress. The exponent $n$ can be written as follows [26]:

$$
n=\left(\frac{\partial \ln \dot{\varepsilon}_{\min }}{\partial \ln \sigma}\right)_{T}
$$

The decrease in $n$ at the lower stresses can indicate some changes in the rate-controlling creep deformation mechanism(s), microstructural instability and/or the presence of threshold stress. The determined values of $n$ correspond to the power-law dislocation creep regime [26]. Figure 7 shows the variation in the time to fracture $t_{f}$ with the applied stress. It can be easily seen from this plot that the values of the stress exponent $m$ of creep life (see Equation (2)) are very similar to the values of the stress exponent $n$, indicating that both the creep deformation and fracture could be controlled by the same operating mechanism(s) [26]:

$$
t_{f} \approx B \cdot \sigma^{-m}, \text { where } \mathrm{m}=-\left(\frac{\partial \ln t_{f}}{\partial \ln \sigma}\right)_{T}
$$

Table 3 contains the values of the exponents $n$ and $m$ for each superalloy at different temperatures. With respect to non-linear curves in bilogarithmic plots, the values of $n$ and $m$ were determined as partial local slopes of the relevant curves.

Table 3. Values of the stress exponents of the creep rate $n$ and the creep life $m$ for superalloys INC 713 LC, B1914 and MAR-M247 for different temperatures and the applied stress range used.

\begin{tabular}{ccccccccc}
\hline \multirow{2}{*}{ Superalloy } & \multicolumn{4}{c}{ Parameter $\boldsymbol{c}$} \\
\cline { 2 - 9 } & $\mathbf{8 0 0}{ }^{\circ} \mathbf{C}$ & $\mathbf{9 0 0}{ }^{\circ} \mathbf{C}$ & $\mathbf{9 5 0}{ }^{\circ} \mathbf{C}$ & $\mathbf{1 0 0 0}{ }^{\circ} \mathbf{C}$ & $\mathbf{8 0 0}{ }^{\circ} \mathbf{C}$ & $\mathbf{9 0 0}{ }^{\circ} \mathbf{C}$ & $\mathbf{9 5 0}{ }^{\circ} \mathbf{C}$ & $\mathbf{1 0 0 0}{ }^{\circ} \mathbf{C}$ \\
\hline INC 713 LC & $11-18$ & $6-8$ & $6-11$ & $6-8$ & $8-21$ & $6-7$ & $5-9$ & $5-8$ \\
B1914 & $9-16$ & $5-9$ & $5-10$ & $5-7$ & $6-14$ & $4-8$ & $5-7$ & $4-7$ \\
MAR-M247 & $9-19$ & $7-14$ & $6-9$ & $6-8$ & $8-19$ & $5-14$ & $6-8$ & $5-7$ \\
\hline
\end{tabular}

As far as creep fracture strain of the specimens of each studied superalloy (Figure 8a), the creep experiments revealed generally low levels of creep plasticity, characterized by the values of fracture elongation within the interval 1-10\%. However, while the fracture elongation was about $3 \%$ to $5 \%$ at $800{ }^{\circ} \mathrm{C}$ only, with increasing temperature creep ductility slightly increased for superalloys MAR-M247 and B1914 up to 10\%. A different tendency was observed for INC-713 LC, where the fracture strain reached slightly higher values only when the temperature increased to $1000{ }^{\circ} \mathrm{C}$. Figure $8 \mathrm{~b}$ illustrates the normed ratio of fracture elongation of MAR-M247 and B1914 to the fracture elongation of INC-713LC. It can be clearly seen that the ratio is higher than 1 for nearly all tests. A suitable explanation for the increasing creep plasticity of superalloys MAR-M247 and B1914 from the point of view creep curves can be found in the course of their tertiary stages, which are longer, and their growth is not so rapid in comparison with the creep curves of INC-713 LC. The ratio of creep fracture elongation of MAR-M247 to B1914 is illustrated in Figure 8c. The fracture elongation for B1914 in comparison to values for MAR-M247 is higher for all temperatures except creep temperature $1000^{\circ} \mathrm{C}$. 
In summary, based on the evaluation of the main creep parameters, the superalloy MAR-M247 exhibits the best creep properties of the three superalloys evaluated. B1914 shows somewhat worse creep characteristics, even at the highest temperature of $1000{ }^{\circ} \mathrm{C}$, than MAR-M247, and the superalloy INC-713 LC has the worst qualities in this comparison. However, it should be noted that each of the compared superalloys can be used for producing high temperature components for rated operating conditions.

\subsection{Fracture}

Generally, the creep fracture behaviour of the three studied superalloys strongly depends on temperature and applied stress, but also on the chemical composition and structure of the alloys. After creep testing, the fracture surfaces and metallographic cross sections parallel to the loading axis of the crept specimens were examined with the SEM. The features of fracture surfaces of specimens crept at $800{ }^{\circ} \mathrm{C}$ and $400 \mathrm{MPa}$ are shown in Figure 9. The corresponding micrographs in Figure 10, taken from longitudinal sections, show the fracture profiles. The fractographic observations of the fracture surfaces clearly indicate that the fracture is a brittle mostly mixed transgranular (intradendritic) and intergranular mode, resulting in relatively low values of the strain to fracture $\varepsilon_{\mathrm{f}}$ (Figure 8a). The final fracture is initiated by the loss of external sections of the specimen due to local necking as a result of instability, plastic deformation and by the loss of internal sections due to the formation and growth of surface and internal cracks. The possible changes in fracture mode and participated fracture mechanism(s) can be connected with a varied level of reduction in cross areas of the specimen (necking), which can lead to an increase in applied stress at this area and to the acceleration of microstructural instability. In particular, the carbide morphologies are significantly affected by the applied stress.

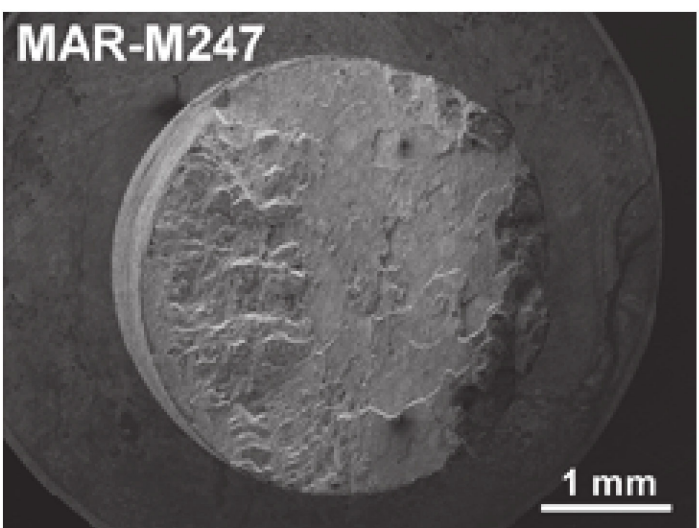

(a)

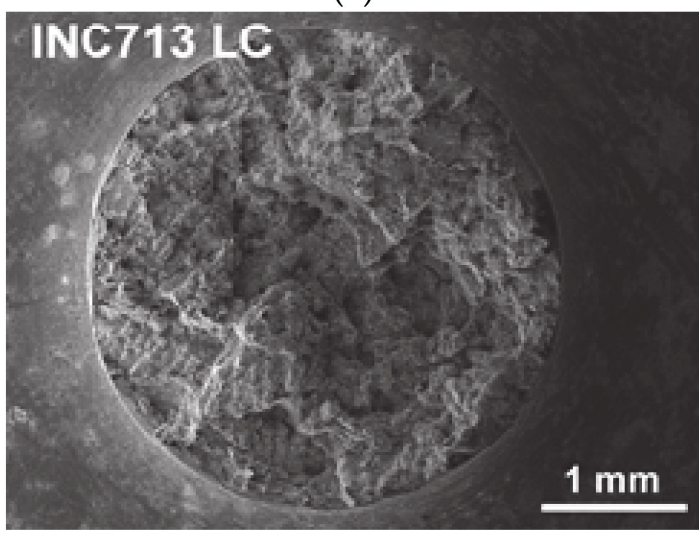

(c)

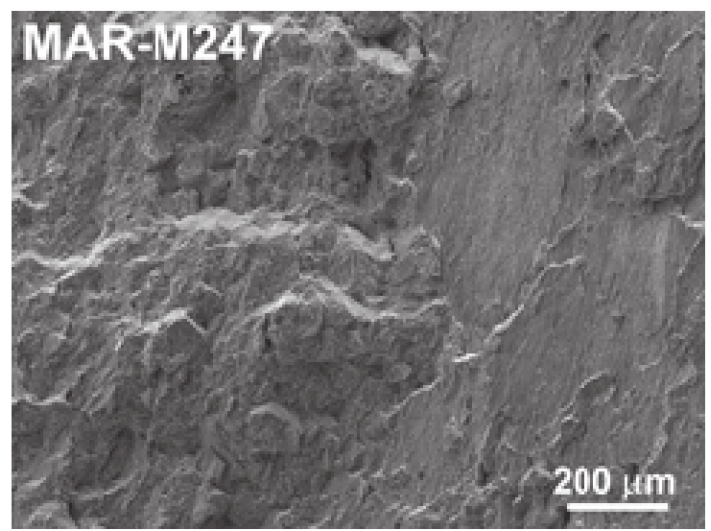

(b)

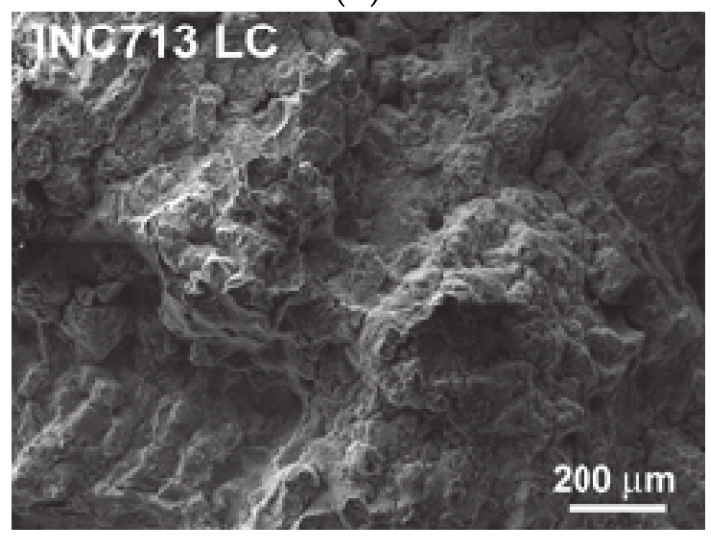

(d)

Figure 9. Cont. 


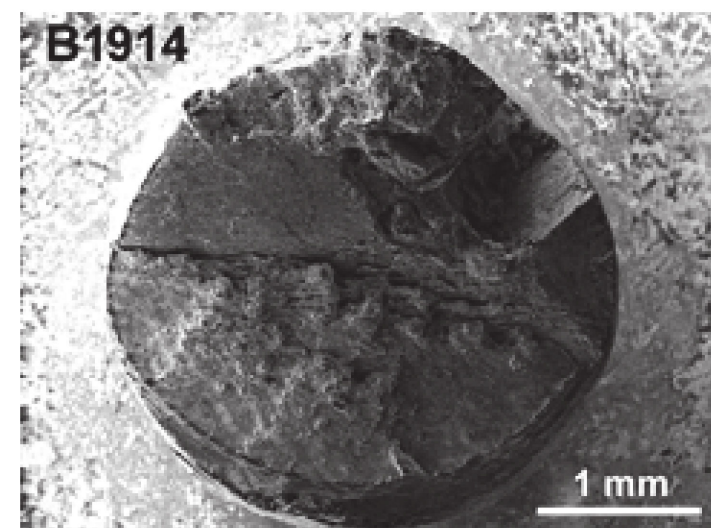

(e)

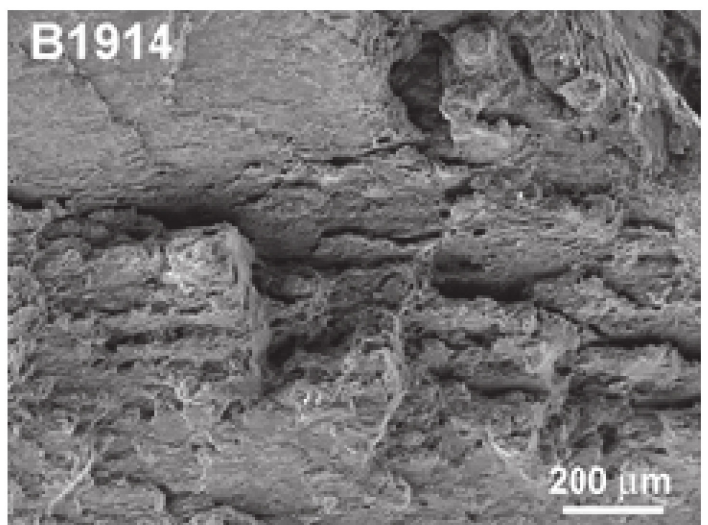

$(\mathbf{f})$

Figure 9. Fracture surfaces of specimens crept at $800{ }^{\circ} \mathrm{C}$ and $400 \mathrm{MPa} —$ overall view and corresponding detail of superalloy MAR-M247 (a,b), INC 713 LC (c,d) and B1914 (e,f).

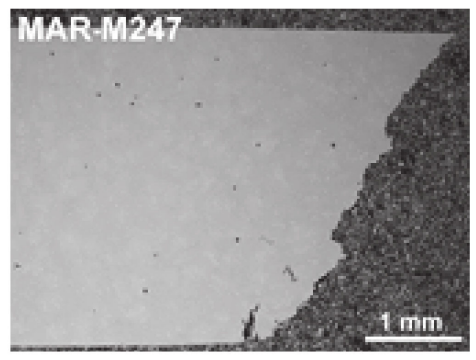

(a)

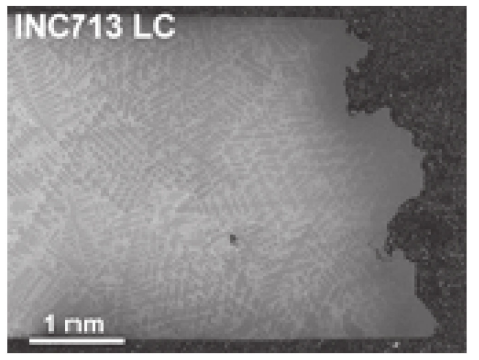

(b)

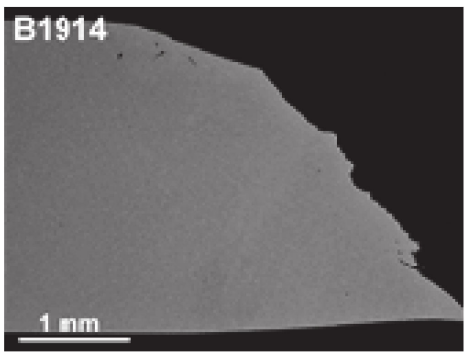

(c)

Figure 10. Longitudinal section of specimens' gauge part (crept at $800{ }^{\circ} \mathrm{C}$ and $400 \mathrm{MPa}$ —of superalloy MAR-M247 (a), INC 713 LC (b) and B1914 (c). The stress axis is horizontal.

The type of fracture could also be changed by the increasing temperature. Figure 11 illustrates fracture surfaces taken by SEM of specimens crept at $1000{ }^{\circ} \mathrm{C}$ and $950{ }^{\circ} \mathrm{C}$ for superalloys MAR-M247, B1914 and INC713 LC. All of them exhibit a mostly transgranular character with a higher reduction in fracture area in the MAR-M247 and B1914 specimens. The specimens of all superalloys also exhibit small cracks from the surface on the gauge length (Figure 12), which could be responsible for the formation and propagation of the main crack [27].

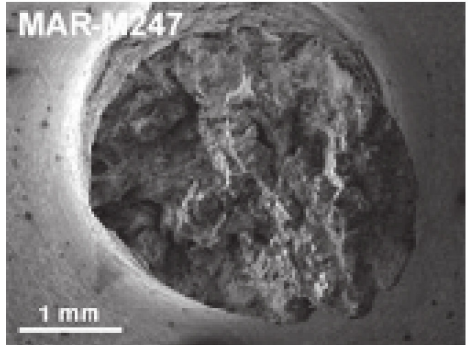

(a)

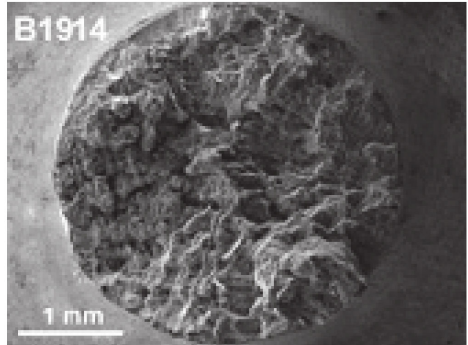

(b)

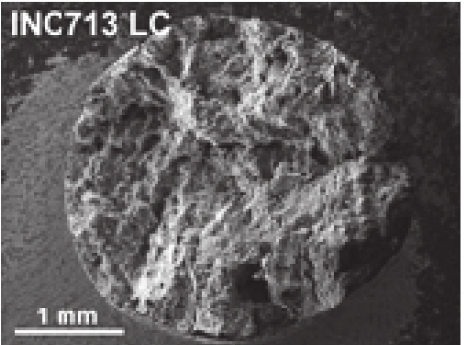

(c)

Figure 11. Fracture surfaces of specimens crept at $1000^{\circ} \mathrm{C}$ and $100 \mathrm{MPa}$-superalloy MAR-M247 (a), B1914 (c), and crept at $950^{\circ} \mathrm{C}$ and $400 \mathrm{MPa}$ - superalloy INC $713 \mathrm{LC}(\mathbf{b})$. 


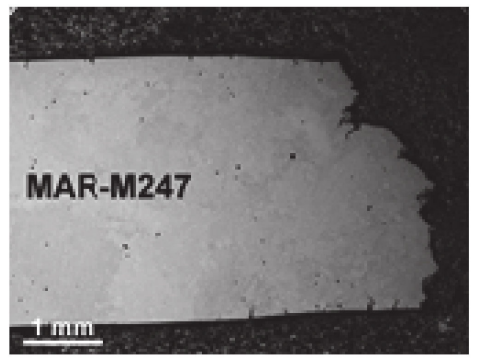

(a)

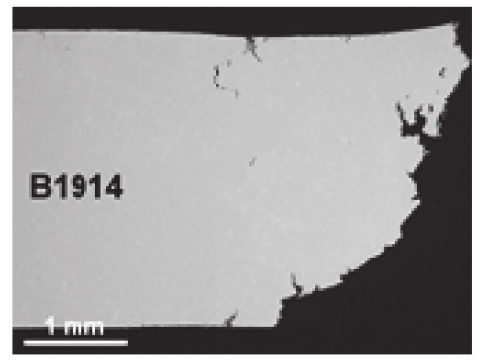

(b)

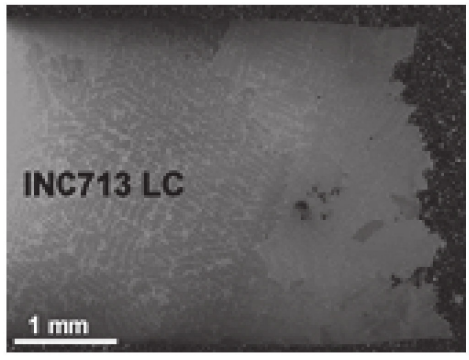

(c)

Figure 12. Longitudinal sections of specimens' gauge part crept at $100{ }^{\circ} \mathrm{C}$ and $100 \mathrm{MPa}$-superalloy MAR-M247 (a), B1914 (c), and crept at $950^{\circ} \mathrm{C}$ and $400 \mathrm{MPa}$-superalloy INC $713 \mathrm{LC}$ (b). The stress axis is longitudinal.

\section{Discussion}

All three studied cast nickel-based superalloys, MAR-M247, INC713 LC and B1914, are polycrystalline, and their excellent mechanical properties are caused by the presence of precipitate strengthened by inter-metallic gamma-prime phase, enhanced by solid solution strengthening and grain boundary strengthening. In addition, precipitation strengthening by carbides and borides in the vicinity of grain boundaries plays an important factor in improving the mechanical properties. The differences at the chemical composition and, consequently, of their microstructure can be the reason for their different creep behaviours [17].

As mentioned earlier, standard uniaxial constant load creep tests of the three types of superalloys were carried out at four temperatures, 800, 900, 950 and $1000{ }^{\circ} \mathrm{C}$, and a wide range of applied stress, from 150 to $700 \mathrm{MPa}$. The alloys exhibit a relatively short secondary creep region, which can be considered to calculate the minimum creep rate (Figures 2-5). The microstructure is not stable during high-temperature creep, resulting in the acceleration of the secondary creep rate, leading to the tertiary creep stage $[28,29]$. The superalloy MAR-M247 exhibits the best creep properties, such as lowest minimum creep rate and longest time to fracture, out of all three superalloys. On the contrary, creep results from the superalloy INC713 LC show several times worse values of the minimum creep rate and time to fracture in comparison with MAR-M247. Creep curves of the material B1914 lie in between the curves of the other two superalloys. It can be clearly seen from Figures 2-5 that the third stage of MAR-M247's creep curves is extended in comparison with B1914, and even more markedly with INC713 LC.

The inspection of stress dependences of the minimum creep rate and the time to fracture (Figures 6 and 7) reveals the changing of the stress exponent of minimum creep rate $n$ (Equation (1)) and the stress exponent of time to fracture $m$ (Equation (2)). These variations have the same tendency for all temperatures and superalloys used. The decrease in $n$ at the lower stresses may be indicative of some changes in the rate-controlling creep deformation mechanism(s), microstructural instability and/or the presence of threshold stress.

The analyses of the regime in which the creep tests were performed and an identification of creep mechanisms which operate in this regime are essential for understanding the creep behaviour of the superalloys under investigation. The inspection of stress dependences of the minimum creep rate and the time to fracture (Figures 6 and 7) reveals the changing of the stress exponent of minimum creep rate $n$ (Equation (1)) and the stress exponent of time to fracture $m$ (Equation (2)). These variations have the same tendency for all temperatures and superalloys used. The fact that the stress exponent of the minimum creep rate $n$ is not constant may be indicative of changes in the rate-controlling creep deformation mechanism(s), microstructural instability and/or the presence of threshold stress $\sigma_{0}$.

The experimentally determined values of $n$ (Table 3 ), especially at lower temperatures and higher applied stresses, are somewhat high compared to those predicted by dislocation climb controlled models of power-law dislocation creep of the precipitate hardened 
materials [26,30], but do not comply with the criterion proposed by Sherby and Burke [31] for power-law stress region break down. A gradual increase in the stress exponent may be due to the overlapping of the stress intervals-a characteristic for the dislocation climb and the Orowan mechanism [26,30,31]. The highest values of the exponent $n$ probably involved internal stresses, in addition to a power-law dependence of the flow rate. Thus, one explanation of such high values of stress exponent $n$ can be based on the idea that the creep behaviour of the nickel-based alloys is controlled by precipitation hardening, resulting from the interaction of mobile dislocations with the precipitates, and the creep behaviour of the alloys is not driven by the applied stress, $\sigma$, but an effective stress, $\sigma_{\text {eff }}$ [26]:

$$
\sigma_{e f f}=\sigma-\sigma_{0}
$$

where $\sigma_{0}$ is the threshold stress. Thus, the experimentally determined values, $n$, (Table 3 ) could be rationalized by considering the existence of the threshold stress. For the applied stress, $\sigma$, and a selected testing temperature, $T$, a simple Norton power-law constitutive relation gives:

$$
\dot{\varepsilon}_{\min }=A \cdot \sigma^{n}
$$

where $A$ is an empirical structural parameter. Equation (4) can be reduced to Equation (5) or Equation (6):

$$
\begin{gathered}
\dot{\varepsilon}_{\min }=A_{1}\left(\sigma-\sigma_{0}\right)^{n} \\
\left(\dot{\varepsilon}_{\min }\right)^{1 / n}=A_{2}\left(\sigma-\sigma_{0}\right)
\end{gathered}
$$

The threshold stress, $\sigma_{0}$, can be evaluated graphically for prior selected values of the stress exponent $n$ by plotting $\left(\dot{\varepsilon}_{\min }\right)^{1 / n}$ vs. $\sigma$ on linear axes [32]. The plot is extrapolated linearly to an intersect of the stress axis at zero strain rate. This intersect of best fit lines on the stress axis is the threshold stress, $\sigma_{0}$. This procedure was followed for all superalloys under investigation using the selected model value $n=5[26,30]$ for power-law dislocation creep in the precipitation hardened materials (Figure 13). The determined values of the threshold stress, $\sigma_{0}$, are in Table 4 . The significant decrease in the values of the threshold stress, $\sigma_{0}$, with increasing testing temperature could be explained by changes in size (coarsening) and volume fraction, or the interprecipitate spacing (dissolution) of precipitates $[5,6,26,33,34]$. The corrected values of the stress exponents of the minimum creep rate, $n^{*}$, based on their dependence on the effective stress, $\sigma_{\text {eff, }}$ (Figure 14) are listed in Table 5. The corrected values of the true stress exponent, $n *$, correspond to the power-law dislocation creep and suggest dislocation climb and glide as a dominating creep deformation mechanism. However, at the lowest applied stresses, $\sigma$, grain boundary and diffusional mediated processes cannot be excluded. An example of this is grain boundary sliding with the stress rate exponent $n \sim 2[26,35,36]$.

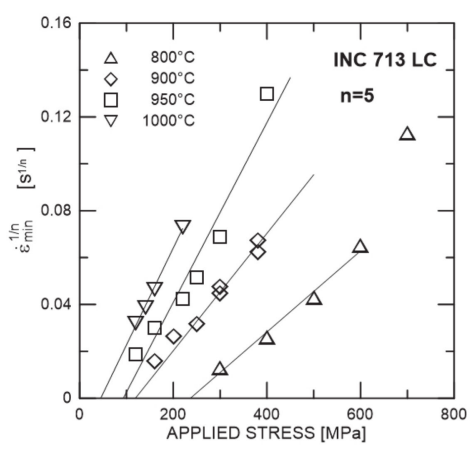

(a)

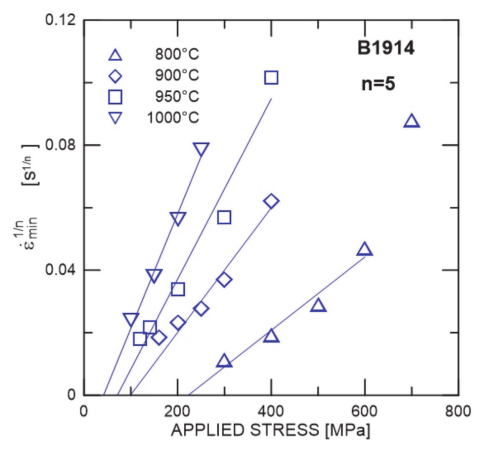

(b)

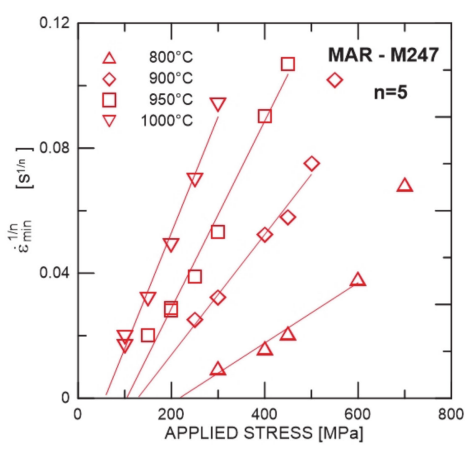

(c)

Figure 13. Estimation of the threshold stress $\sigma_{0}$ for (a) INC 713LC, (b) B1914, and (c) MAR-M247. 
Table 4. Evaluated values of threshold stress $\sigma_{0}$ for all investigated alloys.

\begin{tabular}{cccc}
\hline \multirow{2}{*}{$\mathbf{T}\left({ }^{\circ} \mathbf{C}\right)$} & \multicolumn{3}{c}{$\boldsymbol{\sigma}_{\mathbf{0}}$ (Mpa) } \\
\cline { 2 - 4 } & INC 713LC & B1914 & MAR-M247 \\
\hline 800 & 237 & 223 & 218 \\
900 & 112 & 100 & 128 \\
950 & 94 & 72 & 105 \\
1000 & 46 & 42 & 58 \\
\hline
\end{tabular}

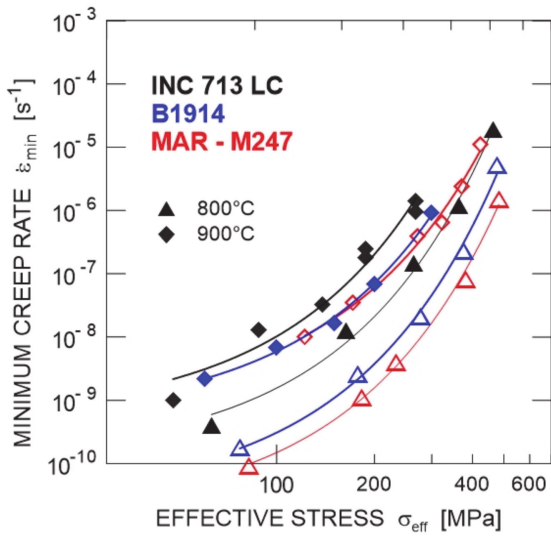

(a)

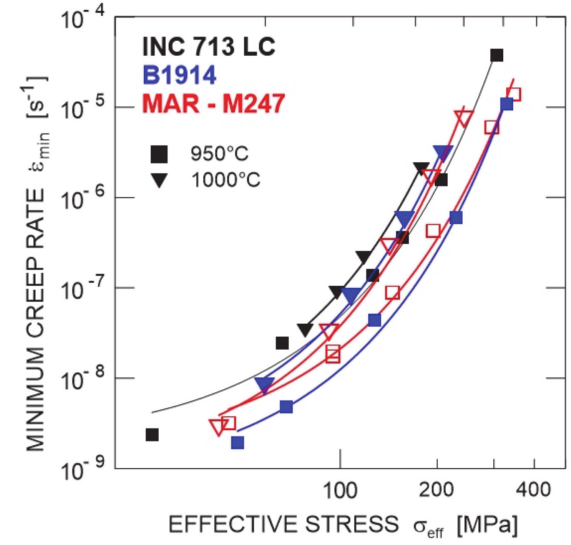

(b)

Figure 14. Dependences of the minimum creep rate $\dot{\varepsilon}_{\min }$ on the effective stress $\sigma_{\text {eff }}=\sigma-\sigma_{0}$ for (a) 800 and $900{ }^{\circ} \mathrm{C}$, and (b) 950 and $1000{ }^{\circ} \mathrm{C}$.

Table 5. Evaluated values of the corrected stress exponent of creep rate $n$ * for all investigated alloys.

\begin{tabular}{ccccc}
\hline \multirow{2}{*}{ Superalloy } & \multicolumn{4}{c}{ Parameter $\boldsymbol{n}^{*}$ for $\sigma_{\text {eff }}$} \\
\cline { 2 - 5 } & $\mathbf{8 0 0}{ }^{\circ} \mathbf{C}$ & $\mathbf{9 0 0}{ }^{\circ} \mathbf{C}$ & $\mathbf{9 5 0}{ }^{\circ} \mathbf{C}$ & $\mathbf{1 0 0 0}{ }^{\circ} \mathbf{C}$ \\
\hline INC 713 LC & $2-11$ & $2-6$ & $2-7$ & $4-6$ \\
B1914 & $2-10$ & $2-6$ & $2-8$ & $2-6$ \\
MAR-M247 & $3-9$ & $3-7$ & $2-7$ & $3-6$ \\
\hline
\end{tabular}

The same conclusion was reported by Liao [37], where the controlling creep mechanism was proposed as dislocation climb and glide too, based on creep tests carried out under constant load at only one temperature $\left(871^{\circ} \mathrm{C}\right)$ and following detailed microstructure observation of the crept specimen. This idea is further supported by a creep deformation map for related superalloy MAR-M200 [17].

Creep deformation in this class of superalloys occurs predominantly in the matrix phase. One further possible deformation mechanism, except dislocation glide, is grain boundary sliding, which could be minimized by a coarser grain size [26]. However, a number of additional microstructural parameters can influence creep in superalloys. Those of primary importance are the $\gamma^{\prime}$ precipitate volume fraction, lattice mismatch and morphology. It was reported [17] that creep life roughly linearly increases with the $\gamma^{\prime}$ volume fraction. The lattice mismatch between the matrix and $\gamma^{\prime}$ also influences the creep strength [38]. For the best creep strength, the $\gamma^{\prime}$ particles should be very small, but this may cause undesirable losses in ductility. In our case, coarse primary $\gamma^{\prime}$ phase particles with an average size of $\sim 0.5$ to $1.5 \mu \mathrm{m}$ were observed in all three superalloys. These large particles could be caused by the microsegregation of alloying elements during the solidification process, and they were difficult to refine or even dissolve during heat treatment.

Carbides also play an important role in creep strengthening, mainly by pinning the grain boundaries and subsequently preventing the grain boundaries from sliding and migration. In B1914, the presence of boron can disorder the grain boundary, allowing easy 
dislocation movement through the grain boundary, lowered local stress and, therefore, preventing the premature initiation of micro-cracks. As a consequence, the grain boundary strengthening is reduced. Thereby, the tensile strength of the B1914 alloy can be depressed for this reason [16].

The ductility of the three studied superalloys is relatively small, and the creep fracture elongation values were measured within the interval 1-10\%. The superalloys MAR-M147 and B1914 exhibit a change in ductility and fracture mode with increasing temperature. The creep fracture elongation of these superalloys was about $3 \%$ to $5 \%$ at $800{ }^{\circ} \mathrm{C}$, and with increasing temperature the creep ductility of the specimens slightly increased up to $10 \%$. With the higher value of temperature, the creep fracture mode changed, as shown by the micrographs of the fracture surfaces. At the lowest temperature, the fracture surfaces exhibit a mixture of transgranular, intradendritic and final shear mode of fracture. Some cleavage marks cannot be excluded. However, an oxides on the fracture surfaces prevents us from making a detailed observation. At the final stage of creep exposure, the fracture area is slightly necked, the concentration of stress in this area increases and a fracture mode changes due to matrix instability to shear mode. At higher temperatures, the ratio of interdendritic types of fracture increases. The small cracks along the gauge length indicate damage in whole specimens, which can be reflected by the third stadium of creep curves. Finally, the coalescence of damage on grain boundaries and cavities inside of the creeping body after some time of creep exposure results in the main crack propagation.

A similar situation of fracture behaviour occurs for the superalloy INC713 LC, but the fracture elongations are considerably smaller in comparison with that of the two other superalloys and slightly increase only at the highest temperature of $1000{ }^{\circ} \mathrm{C}$, where the slight necking of specimens at the fracture area was observed. The sections of gauge length show the presence of cracks, which make the formation of the main crack and a brittle interdendritic mode of fracture easier. This can be explained by the ineffective activity of accommodation processes for creep damage [22].

For $\gamma^{\prime}$ strengthened alloys, loss of ductility is the key issue stemming from microstructural instabilities. Such microstructural changes in the alloys under investigation can be the precipitation of deleterious secondary phases such as TCP-type sigma or Laves phase, which is one of the most important causes of embrittlement [1]. Thus, the precipitation of deleterious phases at higher temperatures in MAR-M247 and B1914 has apparently less effect on the embrittlement than in the case of the INC 713 LC alloy. Moreover, adding the elements $\mathrm{Co}, \mathrm{W}, \mathrm{Hf}$ and Ta to MAR-M247 contributes to creep performance by the formation of $\gamma / \gamma^{\prime}$ eutectic and carbides in the interdendritic areas. Carbides are also present at the grain boundaries, where they provide the pinning effect of these boundaries. Especially, the addition of Ta effectively prevents the coagulation and growth of $\gamma^{\prime}$ phase $[9,11]$. In the B1914 superalloy, the increasing volume of B causes the formation of stable borides in grain boundaries, which can facilitate the cross slip of dislocations across the boundaries and reduce the risk of cracking $[16,18]$. Thereby, the tensile strength of the B1914 alloy is depressed. However, the rupture life and the ductility can be improved.

\section{Conclusions}

The present study is focused on the mutual comparison of the creep behaviour and properties of three precipitate-hardened nickel-based superalloys, MAR-M247, INC713 LC and B1914, the evaluation of their creep and fracture parameters and the identification of acting creep deformation mechanism(s). Standard constant load creep tests in tension were carried out at the applied stresses ranging from 150 to $700 \mathrm{MPa}$, and temperatures of 800 , 900,950 and $1000{ }^{\circ} \mathrm{C}$. The conclusions are summarized as follows:

(1) The experimentally determined values of the stress exponent of the minimum creep rate $n$ were rationalized by considering the existence of the threshold stress $\sigma_{0}$. The corrected values of the stress exponent $n$ indicate that the creep tests were performed in the power-law regime and imply that dislocation climb and glide are the dominat- 
ing creep deformation mechanisms. Nevertheless, at the lower applied stresses, grain boundary and diffusion mediated mechanisms cannot be excluded.

(2) The observed decrease in the threshold stress $\sigma_{0}$ with increasing testing temperature was explained by changes in the size and density of precipitates.

(3) Fractographic investigation revealed that, under testing conditions, the creep fracture is a brittle mostly mixed transgranular and intergranular mode, resulting in relatively low values of the fracture strain.

(4) Based on a comparison of the main creep parameters, such as the minimum creep rate and the time to fracture, determined under the identical loading conditions, superalloy MAR-M247 exhibits the best creep properties of the three tested superalloys. B1914 shows worse creep characteristics, even at the highest temperature of $1000{ }^{\circ} \mathrm{C}$, than MAR-M247. The superalloy INC713 LC in this comparison has the worst creep properties. However, it should be concluded that each of the investigated superalloys can be successfully used for high temperature components fulfilling the required service loading conditions.

Author Contributions: Conceptualization, M.K.; methodology, M.K.; creep measurements, M.K. and J.D.; creep data analysis, M.K.; original draft preparation, M.K.; microscopy, M.K. and P.K.; Analysis of creep and fracture mechanisms, V.S. All authors have read and agreed to the published version of the manuscript.

Funding: This research was financially supported by the project CZ.01.1.02/0.0/0.0/19_262/0020138 of the Ministry of Industry and Trade of the Czech Republic.

Institutional Review Board Statement: Not applicable.

Informed Consent Statement: Not applicable.

Data Availability Statement: Data is contained within the article.

Conflicts of Interest: The authors declare no conflict of interest.

\section{References}

1. Reed, R.C. The Superalloys: Fundamentals and Applications; Cambridge University Press: Cambridge, UK, 2008; ISBN 978-1-13945863-4.

2. Donachie, M.J.; Donachie, S.J. Superalloys: A Technical Guide; ASM International: Novelty, OH, USA, 2002; ISBN 978-1-62708-267-9.

3. Di Gianfrancesco, A. Materials for Ultra-Supercritical and Advanced Ultra-Supercritical Power Plants; Woodhead Publishing: Cambridge, UK, 2016; ISBN 978-0-08-100558-3.

4. Podrábský, T.; Vysoké Učení Technické v Brně; Ústav Materiálových Věd a Inženýrství. Vliv Podmínek Zatěžování na Strukturu a Porušování Lité Niklové Superslitiny = Influence of the Loading Factors' Condi-tions on the Structure and Failure of the Cast Nickel Superalloy. In Teze Přednášky k Profesorskému Jmenovacímu Řizení v Oboru Materiálové Vědy a Inženýrství; VUTIUM: Brno, Czech Republic, 2005; ISBN 978-80-214-3018-1.

5. Boutarek, N.; Saïdi, D.; Acheheb, M.A.; Iggui, M.; Bouterfaïa, S. Competition between Three Damaging Mechanisms in the Fractured Surface of an Inconel 713 Superalloy. Mater. Charact. 2008, 59, 951-956. [CrossRef]

6. Azadi, M.; Marbout, A.; Safarloo, S.; Azadi, M.; Shariat, M.; Rizi, M.H. Effects of Solutioning and Ageing Treatments on Properties of Inconel-713C Nickel-Based Superalloy under Creep Loading. Mater. Sci. Eng. A 2018, 711, 195-204. [CrossRef]

7. Azadi, M.; Azadi, M. Evaluation of High-Temperature Creep Behavior in Inconel-713C Nickel-Based Superalloy Considering Effects of Stress Levels. Mater. Sci. Eng. A 2017, 689, 298-305. [CrossRef]

8. Francis, E.M.; Grant, B.M.B.; Fonseca, J.Q.d.; Phillips, P.J.; Mills, M.J.; Daymond, M.R.; Preuss, M. High-Temperature Deformation Mechanisms in a Polycrystalline Nickel-Base Superalloy Studied by Neutron Diffraction and Electron Microscopy. Acta Mater. 2014, 74, 18-29. [CrossRef]

9. Kvapilova, M.; Dvorak, J.; Kral, P.; Hrbacek, K.; Sklenicka, V. Creep Behaviour and Life Assessment of a Cast Nickel-Base Superalloy MAR-M247. High Temp. Mater. Process. 2019, 38, 590-600. [CrossRef]

10. Maggiani, G.; Roy, M.J.; Colantoni, S.; Withers, P.J. MAR-M-247 Creep Assessment through a Modified Theta Projection Model. Materialia 2019, 7, 100392. [CrossRef]

11. Baldan, R.; da Rocha, R.L.P.; Tomasiello, R.B.; Nunes, C.A.; da Silva Costa, A.M.; Barboza, M.J.R.; Coelho, G.C.; Rosenthal, R. Solutioning and Aging of MAR-M247 Nickel-Based Superalloy. J. Mater. Eng. Perform 2013, 22, 2574-2579. [CrossRef]

12. Liu, S.; Liu, C.; Ge, L.; Zhang, X.; Yu, T.; Yan, P.; Wang, C. Effect of Interactions between Elements on the Diffusion of Solutes in NiXY Systems and $\Gamma^{\prime}$-Coarsening in Model Ni-Based Superalloys. Scr. Mater. 2017, 138, 100-104. [CrossRef] 
13. Lee, C.S.; Han, G.W.; Smallman, R.E.; Feng, D.; Lai, J.K.L. Influence of Boron-Doping on the Effectiveness of Grain Boundary Hardening in Ni3Al. Acta Mater. 1999, 47, 1823-1830. [CrossRef]

14. Khadkikar, P.S.; Vedula, K.; Shabel, B.S. Role of boron in ductilizing Ni ${ }_{3}$ Al. Metall. Trans. A Phys. Metall. Mater. Sci. 1987, 18 A, 425-428. [CrossRef]

15. Schulson, E.M.; Weihs, T.P.; Baker, I.; Frost, H.J.; Horton, J.A. Grain Boundary Accommodation of Slip in Ni3Al Containing Boron. Acta Metall. 1986, 34, 1395-1399. [CrossRef]

16. Zhou, P.J.; Yu, J.J.; Sun, X.F.; Guan, H.R.; Hu, Z.Q. The Role of Boron on a Conventional Nickel-Based Superalloy. Mater. Sci. Eng. A-Struct. Mater. Prop. Microstruct. Process. 2008, 491, 159-163. [CrossRef]

17. Wiley-Interscience. Superalloys II: High-Temperature Materials for Aerospace and Industrial Power, 2nd ed.; Sims, C.T., Stoloff, N.S., Hagel, W.C., Eds.; Wiley-Interscience: New York, NY, USA, 1987; ISBN 978-0-471-01147-7.

18. Da Silva Costa, A.M.; Nunes, C.A.; Baldan, R.; Coelho, G.C. Thermodynamic Evaluation of the Phase Stability and Microstructural Characterization of a Cast B1914 Superalloy. J. Mater. Eng. Perform 2014, 23, 819-825. [CrossRef]

19. Seo, S.M.; Kim, I.S.; Lee, J.H.; Jo, C.Y.; Miyahara, H.; Ogi, K. Eta Phase and Boride Formation in Directionally Solidified Ni-Base Superalloy IN792 + Hf. Met. Mater. Trans. A 2007, 38, 883-893. [CrossRef]

20. Shulga, A.V. Boron and Carbon Behavior in the Cast Ni-Base Superalloy EP962. J. Alloy. Compd. 2007, 436, 155-160. [CrossRef]

21. Shi, Z.; Dong, J.; Zhang, M.; Zheng, L. Solidification Characteristics and Segregation Behavior of Ni-Based Superalloy K418 for Auto Turbocharger Turbine. J. Alloy. Compd. 2013, 571, 168-177. [CrossRef]

22. Baker, I.; Schulson, E. On Grain-Boundaries in Nickel-Rich Ni3al. Scr. Metall. 1989, 23, 1883-1886. [CrossRef]

23. Brusso, J.A.; Mikkola, D.E. Effects of Boron on the Deformation Behavior of Ni3Al. J. Mater. Res. 1994, 9, 1742-1754. [CrossRef]

24. Kvapilová, M.; Kuchařová, K.; Hrbáček, K.; Sklenička, V. Creep Processes in MAR-M247 Nickel-Base Superalloy. Available online: https: / / www.scientific.net/SSP.258.603 (accessed on 22 September 2020).

25. Chen, J.; Lee, J.H.; Jo, C.Y.; Choe, S.J.; Lee, Y.T. MC Carbide Formation in Directionally Solidified MAR-M247 LC Superalloy. Mater. Sci. Eng. A 1998, 247, 113-125. [CrossRef]

26. Čadek, J. Creep in Metallic Materials; Elsevier: Amsterdam, The Netherlands, 1988; ISBN 978-0-444-98916-1.

27. Sklenicka, V. High Temperature Intergranular Damage and Fracture. Mater. Sci. Eng. A 1997, 234-236, 36. [CrossRef]

28. Safari, J.; Nategh, S. Microstructure Evolution and Its Influence on Deformation Mechanisms during High Temperature Creep of a Nickel Base Superalloy. Mater. Sci. Eng. A 2009, 499, 445-453. [CrossRef]

29. Reed, R.C.; Matan, N.; Cox, D.C.; Rist, M.A.; Rae, C.M.F. Creep of CMSX-4 Superalloy Single Crystals: Effects of Rafting at High Temperature. Acta Mater. 1999, 47, 3367-3381. [CrossRef]

30. Kassner, M.E. Fundamentals of Creep in Metals and Alloys, 2nd ed.; Elsevier: Amsterdam, The Netherlands; Elsevier: Boston, MA, USA, 2009; ISBN 978-0-08-047561-5.

31. Sherby, O.D.; Burke, P.M. Mechanical Behavior of Crystalline Solids at Elevated Temperature. Prog. Mater. Sci. 1968, 13, 323-390. [CrossRef]

32. Lagneborg, R.; Bergman, B. The Stress/Creep Rate Behaviour of Precipitation-Hardened Alloys. Met. Sci. 1976, 10, 20-28. [CrossRef]

33. Kim, I.S.; Choi, B.-G.; Jung, J.E.; Do, J.; Seok, W.-Y.; Lee, Y.-H.; Jeong, I.-Y. Effect of Heat Treatment on Microstructural Evolution and Creep Behaviors of a Conventionally Cast Nickel-Based Superalloy. Mater. Charact. 2020, 165, 110378. [CrossRef]

34. Bagui, S.; Sahu, B.P.; Laha, K.; Tarafder, S.; Mitra, R. Creep Deformation Behavior of Inconel 617 Alloy in the Temperature Range of $650{ }^{\circ} \mathrm{C}$ to $800^{\circ} \mathrm{C}$. Met. Mater. Trans. A 2021, 52, 94-107. [CrossRef]

35. Sklenička, V.; Čadek, J. Determination of Strain Component Caused by Grain Boundary Sliding. Z. Met. 1970, 61, 575-580.

36. Sklenicka, V.; Dvorak, J.; Kral, P.; Stonawska, Z.; Svoboda, M. Creep Processes in Pure Aluminium Processed by Equal-Channel Angular Pressing. Mater. Sci. Eng. A 2005, 410-411, 408-412. [CrossRef]

37. Liao, J.-H.; Bor, H.-Y.; Wei, C.-N.; Chao, C.-G.; Liu, T.-F. Influence of Microstructure and Its Evolution on the Mechanical Behavior of Modified MAR-M247 Fine-Grain Superalloys at $871{ }^{\circ}$ C. Mater. Sci. Eng. A 2012, 539, 93-100. [CrossRef]

38. Coakley, J.; Lass, E.A.; Ma, D.; Frost, M.; Stone, H.J.; Seidman, D.N.; Dunand, D.C. Lattice Parameter Misfit Evolution during Creep of a Cobalt-Based Superalloy Single Crystal with Cuboidal and Rafted Gamma-Prime Microstructures. Acta Mater. 2017, 136, 118-125. [CrossRef] 